\title{
Escherichia Coli: Characteristics of Carbapenem Resistance and Virulence Factors
}

\author{
Esra Deniz Candan ${ }^{1} *$, Nilüfer Aksöz ${ }^{1}$. \\ ${ }^{1}$ Department of Biology, Faculty of Science, Hacettepe University, Ankara, Turkey.
}

\begin{abstract}
In this study, fifty Escherichia coli strains were analyzed by multiplex polymerase chain reaction for the genes expressed carbapenemase and virulence factors in order to determine the presence of carbapenemase and nine virulence factors and investigate the association between these two characteristics. When carbapenemase susceptibility was taken into consideration, OXA-48 type carbapenemase was determined for $22 \%$ of the total strains. Also, the frequency of virulence gene regions in E.coli infections and virulence gene profiles of these isolates were examined and the frequency of pap, afa, sfa, fimA, iroN, aer, iutA, hly and cnf-1 genes were 24, 38, 20, 84, 28, 90, 92, 10 and 34\% respectively. A significant correlation was found between the presence of fimA and afa gene regions and carbapenem susceptibility $(P<0.05)$. Based on the combination of carbapenemase and virulence factor genes, 24 different gene profiles were determined for all strains. The results of the study appear to indicate that fimA and afa genes correlate with carbapenem susceptibility, the relations of fimA with urinary tract infections and pap with complicated urinary tract infections. It also indicates that sfa and afa genes correlate with other infections except urinary tract infections.
\end{abstract}

Key words: Carbapenemase; Escherichia coli; multiplex polymerase chain reaction; virulence factor.

\footnotetext{
*Author for correspondence: esradenizcandan@gmail.com
} 


\section{INTRODUCTION}

Escherichia coli causes urinary tract infections, neonatal meningitis, sepsis and intestinal infections more frequently than other members of the Enterobacteriaceae and it is responsible for $80 \%$ of community-acquired urinary tract infections. ${ }^{1}$

Extended-spectrum beta-lactamases (ESBL) which hydrolyze penicillins, cephalosporins, monobactams and generally inhibited by beta-lactamase inhibitors such as clavulanic acid, sulbactam and tazobactam can be produced by the members of Enterobacteriaceae. ${ }^{2}$ The increasing usage of carbapenems, the first treatment option in ESBL producing E. coli infections, has brought out the problem of carbapenem resistance. ${ }^{3}$ Carbapenems was firstly identified in clinical isolate of Enterobacter cloacae ${ }^{4}$ and then carbapenem-resistant Enterobacteriaceae was reported from around the world. ${ }^{5}$ Serine carbapenemases (KPC and OXA-48) and metallo-beta-lactamases (VIM, IMP and NDM) are the most commonly seen among carbapenemases. ${ }^{5}$

E.coli strains have some gene regions responsible for virulence factors which may encode adhesins, toxins, siderophores and haemolysin. Type 1 fimbriae, coded by plasmid-mediated fimA gene and commonly found in these strains from lower urinary system infections, enable E.coli to adhere to human ureteral mucosa epithelial cells. ${ }^{6} \mathrm{P}$ fimbriae that is expressed by plasmid-mediated pap (pyelonephritis-associated pili) gene, is produced by E.coli colonization of upper urinary system. ${ }^{7}$ Afimbrial adhesin encoded by plasmid- or chromosom- mediated $a f a$ and $\mathrm{S}$ fimbriae encoded by plasmid $s f a$ gene regions are commonly found in urinary system infection originated in isolates as well as sepsis and meningitis. ${ }^{8,9}$

Siderophores commonly found in E.coli isolates are aerobactin and ferric aerobactin, encoded by aer and iutA genes. ${ }^{10}$ Also, salmochelin type siderophore encoded by iroN gene in recent years has become important. ${ }^{11}$ These genes are expressed as plasmid-mediated and they are especially related to necrotoxigenic, uropathogenic and septicemic E.coli isolates causing urinary tract infections, septicemia, bacteremia and systemic infections. ${ }^{6,12}$ Also, cytotoxic necrotizing factor 1 (cnf- 1 ) and haemolysin (hly) toxins are important for diversity of E.coli infections ${ }^{13,14}$ and these gene regions expressed by plasmids are mostly produced by uropathogenic E.coli strains. $^{15}$

The aim of the study is to determine the presence of carbapenemase and virulence factors of E.coli clinical specimens and evaluate the possible correlations between carbapenem resistance and virulence factors. Also, the frequency of virulence gene regions in E.coli infections and virulence genotypes of these isolates were determined.

\section{MATERIAL AND METHODS}

\section{Bacterial strains and identification}

In this study, E.coli strains (n=50), obtained from clinical specimens including abscess, bronchial, urea, blood, plevral efusion, tracheal, wound, catheter, body and ear fluid, were collected from three different hospitals in Ankara. Conventional methodology (Gram staining, hemolysis of blood agar, string test, IMViC tests, lactose fermentation, ornithine decarboxylase and motility tests), automatized system (Vitek-32 System, bioMerrieux, France) and CHROMagar Orientation (CHROMagar Company, Paris, France) were used for identification of the strains. 


\section{Antimicrobial susceptibility testing}

Susceptibility to extended spectrum beta lactamases (ESBL) and carbapenems were determined with CHROMagar ESBL (CHROMagar Company, Paris, France) ${ }^{16}$ and CHROMagar KPC (CHROMagar Company, Paris, France) ${ }^{17}$ respectively.

\section{DNA isolation}

Genomic and plasmid DNA were isolated using NucleoSpin®Tissue (MachereyNagel, Germany) and NucleoSpin®Plasmid (Macherey-Nagel, Germany) and were stored in $-20^{\circ} \mathrm{C}$.

\section{Multiplex PCR analysis of carbapenemase gene regions}

The reaction conditions were modified from Poirel et al. ${ }^{18}$. The Multiplex PCR mixture consisted of 1 XPCR buffer $\left(20 \mathrm{mM}\right.$ Tris $\mathrm{HCl}, 10 \mathrm{mM}\left(\mathrm{NH}_{4}\right)_{2} \mathrm{SO}_{4}, 10 \mathrm{mM}$ $\mathrm{KCl}, 2 \mathrm{mM} \mathrm{MgSO}_{4}, 0,1 \%$ Triton X-100), 0,05mM dNTP, 2U Taq polymerase (NEB, Beverly, MA), $50 \mu \mathrm{mol} / \mathrm{L}$ each of primers (NEB, Beverly, MA) and $2 \mu 1$ DNA. The primers used in this study are listed in Table 1.

Amplification was carried out with the following thermal cycling conditions: 5 minutes of pre-denaturation at $95^{\circ} \mathrm{C}$, followed by 35 cycles: 1 minute at $95^{\circ} \mathrm{C}, 1$ minute at $52^{\circ} \mathrm{C}, 1$ minute at $72^{\circ} \mathrm{C}$ and 10 minutes of final elongation at $72^{\circ} \mathrm{C}$ (Sensoquest Labcycler, Germany).

Table 1. Carbapenemase gene regions ${ }^{18}$

\begin{tabular}{|c|c|c|c|}
\hline Primer & Sequence* $\left(5^{\prime}-3^{\prime}\right)$ & Gene & Product size (bp) \\
\hline KPC-F & CGTCTAGTTCTGCTGTCTTG & \multirow{2}{*}{$b l a_{K P C}$} & \multirow{2}{*}{798} \\
\hline KPC-R & CTTGTCATCCTTGTTAGGCG & & \\
\hline NDM-1-F & GGTTTGGCGATCTGGTTTTC & \multirow{2}{*}{$b l a_{N D M-1}$} & \multirow{2}{*}{621} \\
\hline NDM-1-R & CGGAATGGCTCATCACGATC & & \\
\hline OXA-48-F & GCGTGGTTAAGGATGAACAC & \multirow{2}{*}{ bla $a_{O X A-48}$} & \multirow{2}{*}{438} \\
\hline OXA-48-R & CATCAAGTTCAACCCAACCG & & \\
\hline IMP-F & GGAATAGAGTGGCTTAAYTCTC & \multirow{2}{*}{$b^{\prime} a_{I M P}$} & \multirow{2}{*}{232} \\
\hline IMP-R & GGTTTAAYAAAACAACCACC & & \\
\hline VIM-F & GATGGTGTTTGGTCGCATA & \multirow{2}{*}{$b l a_{V I M}$} & \multirow{2}{*}{390} \\
\hline VIM-R & CGAATGCGCAGCACCAG & & \\
\hline
\end{tabular}

IMP, imipenem metallo- $\beta$-lactamase; KPC, Klebsiella pneumoniae carbapenemase; NDM, New Delhi metallo- $\beta$ lactamase; OXA, oxacillinase; VIM, verona integron-encoded metallo- $\beta$-lactamase. 


\section{Multiplex PCR analysis of virulence gene regions}

The mix for the detection of pap genes consisted of 2XPCR buffer $(40 \mathrm{mM}$ Tris $\mathrm{HCl}$, $20 \mathrm{mM}_{\left(\mathrm{NH}_{4}\right)_{2} \mathrm{SO}_{4}, 20 \mathrm{mM} \mathrm{KCl}, 4 \mathrm{mM} \mathrm{MgSO}}, 0,2 \%$ Triton X-100), 0,2mM dNTP, 2U Taq polymerase (NEB, Beverly, MA), 2,5 $\mu \mathrm{mol} / \mathrm{L}$ each of primers (NEB, Beverly, MA) and 2,5 $\mu 1 \mathrm{DNA}$. The mix for the detection of other groups (afa-sfafimA, hly-iroN-aer-cnfl-iutA) was at the same concentrations. The primers used in this study are listed in Table 2 .

Table 2. Virulence gene regions of E.coli ${ }^{13,14,19}$

\begin{tabular}{|c|c|c|}
\hline Primer & Sequence (5'-3') & $\begin{array}{l}\text { Product } \\
\text { size (bp) }\end{array}$ \\
\hline $\begin{array}{l}\text { fimA } \\
\text { fimA-F } \\
\text { fimA-R }\end{array}$ & $\begin{array}{l}\text { GTTGTTCTGTCGGCTCTGTC } \\
\text { ATGGTGTTGGTTCCGTTATTC }\end{array}$ & 447 \\
\hline $\begin{array}{l}\text { pap } \\
\text { pap1 } \\
\text { pap2 } \\
\text { pap3 } \\
\text { pap4 }\end{array}$ & $\begin{array}{l}\text { GACGGCTGTACTGCAGGGTGTGGCG } \\
\text { ATATCCTTTCTGCAGGGATGCAATA } \\
\text { GCAACAGCAACGCTGGTTGCATCAT } \\
\text { AGAGAGAGCCACTCTTATACGGACA }\end{array}$ & 336 \\
\hline $\begin{array}{l}\text { sfa } \\
\text { sfa-F } \\
\text { sfa-R }\end{array}$ & $\begin{array}{l}\text { CTCCGGAGAACTGGGTGCATCTTAC } \\
\text { CGGAGGAGTAATTACAAACCTGGCA }\end{array}$ & 410 \\
\hline $\begin{array}{l}\text { aer } \\
\text { aer-F } \\
\text { aer-R }\end{array}$ & $\begin{array}{l}\text { TACCGGATTGTCATATGCAGACCG } \\
\text { AATATCTTCCTCCAGTCCGGAGAAG }\end{array}$ & 602 \\
\hline $\begin{array}{l}\text { cnf-1 } \\
\text { cnf-F } \\
\text { cnf-R }\end{array}$ & $\begin{array}{l}\text { AAGATGGAGTTTCCTATGCAGGAG } \\
\text { CATTCAGAGTCCTGCССTCATTATT }\end{array}$ & 498 \\
\hline $\begin{array}{l}\boldsymbol{h l y} \\
\text { hly-F } \\
\text { hly-R }\end{array}$ & $\begin{array}{l}\text { AACAAGGATAAGCACTGTTCTGGCT } \\
\text { ACCATATAAGCGGTCATTCCCGTCA }\end{array}$ & 1177 \\
\hline $\begin{array}{l}\text { afa } \\
\text { afa-F } \\
\text { afa-R }\end{array}$ & $\begin{array}{l}\text { GCTGGGCAGCAAACTGATAACTCTC } \\
\text { CATCAAGCTGTTTGTTCGTCCGCCG }\end{array}$ & 750 \\
\hline $\begin{array}{l}\text { iutA } \\
\text { iutA-F } \\
\text { iutA-R }\end{array}$ & $\begin{array}{l}\text { GGCTGGACATCATGGGAACTGG } \\
\text { CGTCGGGAACGGGTAGAATCG }\end{array}$ & 300 \\
\hline $\begin{array}{l}\operatorname{iroN} \\
\text { iroN-F } \\
\text { iroN-R }\end{array}$ & $\begin{array}{l}\text { AAGTCAAAGCAGGGGTTGCCCG } \\
\text { GACGCCGACATTAAGACGCAG }\end{array}$ & 665 \\
\hline
\end{tabular}

Amplification was carried out with the following thermal cycling conditions: 5 minutes of pre-denaturation at $95^{\circ} \mathrm{C}$, followed by 30 cycles: 1 minute at $94^{\circ} \mathrm{C}, 1$ minute at $58^{\circ} \mathrm{C}, 1$ minute at $72^{\circ} \mathrm{C}$ and 10 minutes of final elongation at $72^{\circ} \mathrm{C}$ (Sensoquest Labcycler, Germany).

PCR products were analyzed by electrophoresis in a $1.8 \%$ agarose gel at $150 \mathrm{~V}$ for 2 $\mathrm{h}$ in $1 \times$ TBE ( $89 \mathrm{mM}$ Tris, $89 \mathrm{mM}$ Boric Acid and $2 \mathrm{mM}$ EDTA) containing 0.05 $\mathrm{mg} / \mathrm{L}$ ethidium bromide and images were captured by Gel Logic 200 Molecular Imaging System (Kodak; Rochester). 


\section{Data analysis}

The Fisher's Exact Test were performed for all clinical data. $\mathrm{P}$ value of $<0.05$ was considered statistically significant.

\section{RESULTS}

In total, 50 Escherichia coli strains were identified by microbiology standard methods and chromogenic medium.

\section{Analysis of the carbapenemase gene regions}

Among E.coli isolates, plasmid mediated oxacillinase (OXA-48) gene was determined in 11 strains (22\%) (Fig. 1). Carbapenem gene regions of these isolates are given in Figure 1. Similarly, carbapenem resistance in these strains was determined phenotypically, using CHROMagar KPC.

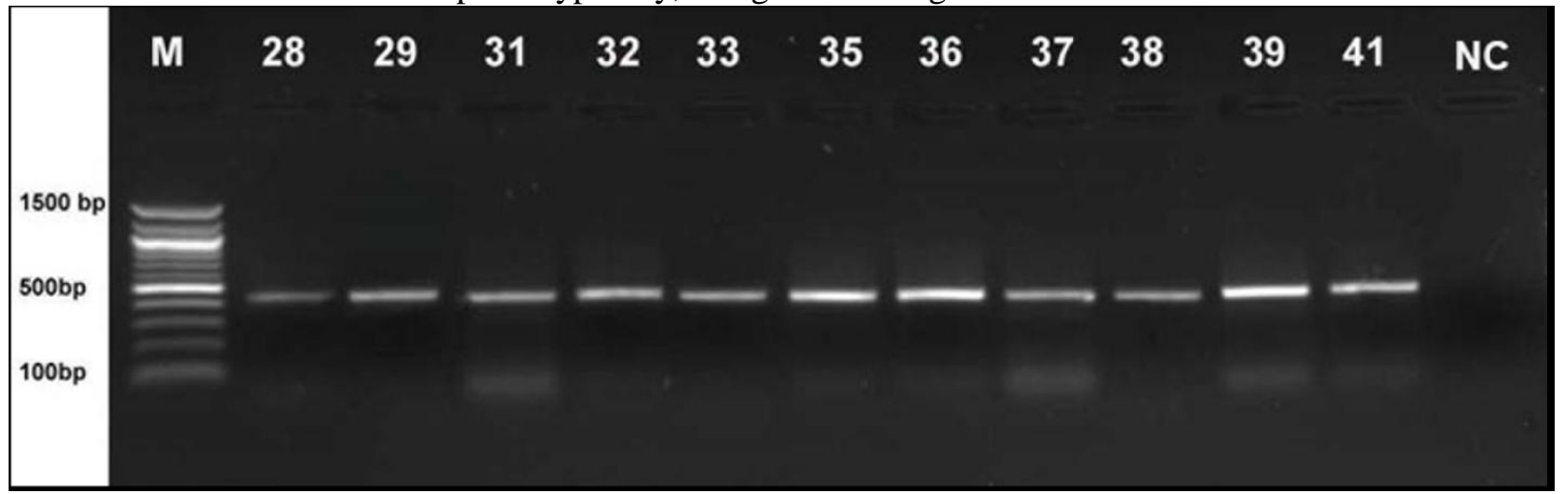

Figure 1. OXA-48 type carbapenemase of E.coli strains (28-41; E.coli, NC; Negative control, M; 100 bp DNA molecular marker).

\section{Analysis of the virulence gene regions}

In this study, nine virulence gene regions (pap, afa, fimA, sfa, hly, iroN, aer, cnf-1 and iutA) for E.coli isolates were analyzed by Multiplex PCR. These gene regions are shown in Figure 2.

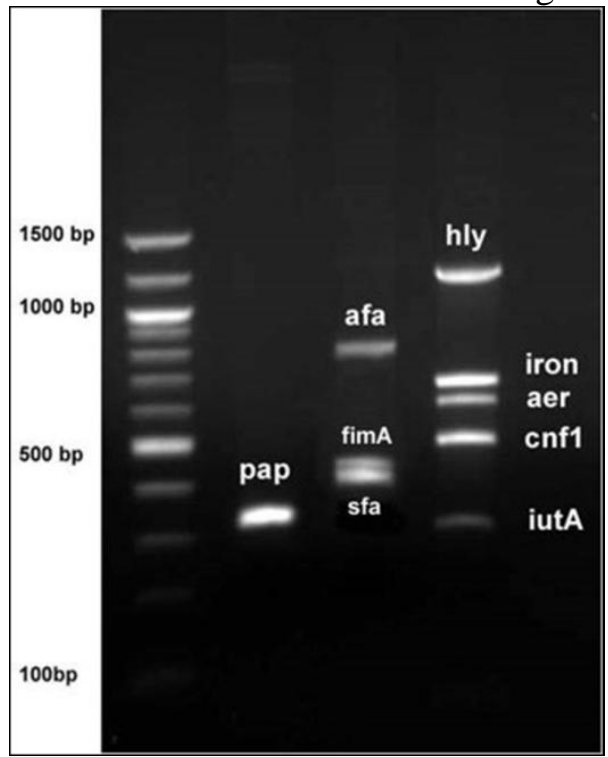

Figure 2. Determined virulence gene regions in E.coli (pap; 328-336 bp, afa; 750 bp, fimA; 447 bp, sfa; 410 bp, hly; 1177 bp, iroN; 665 bp, aer; 602 bp, cnf-1; 498 bp, iutA; 300 bp). 
The distribution of the virulence gene regions in E.coli strains are shown in Figure 3. A high prevalence of virulence genes expressing siderophores (iutA; 92\%, aer; 90\%) in E.coli strains was observed. The Multiplex PCR results showed that among the strains, 84\% were positive for fimA, 38 for afa, 34 for $c n f-1,28$ for iroN, 24 for pap, 20 for $a f a$ and 10 for $h l y$. The least common virulence gene region among strains is hly gene region responsible for hemolysis.

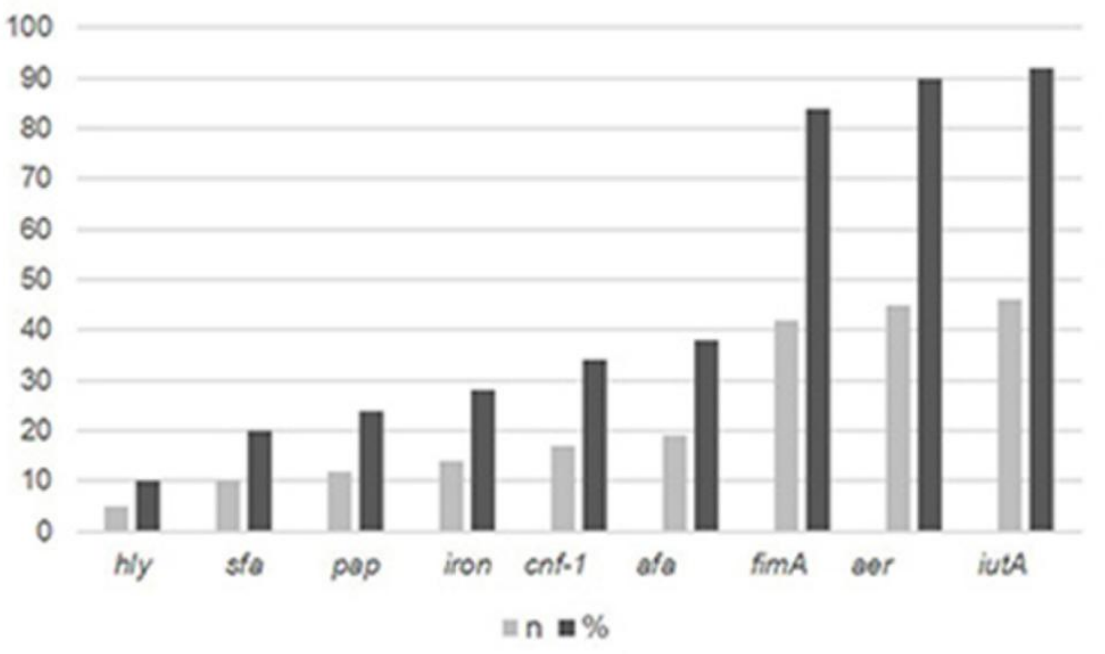

Figure 3. Distribution of virulence gene regions in E.coli strains. " $\mathrm{n}$ " is the number of isolates that were found to possess a given gene; " $\%$ " represents $n$ as the percentage of the 50 strains studied.

Distribution (\%) of virulence factors in different clinical E.coli strains, as distribution of gene regions related with fimbria types (afa, fimA, sfa and pap), siderophore formation (iroN, iutA and aer) and other virulence factors (cnf- 1 and hly), are shown in Figure 4. Great diversity of virulence in urine isolates were observed, whereas any virulence gene is not found in catheter.

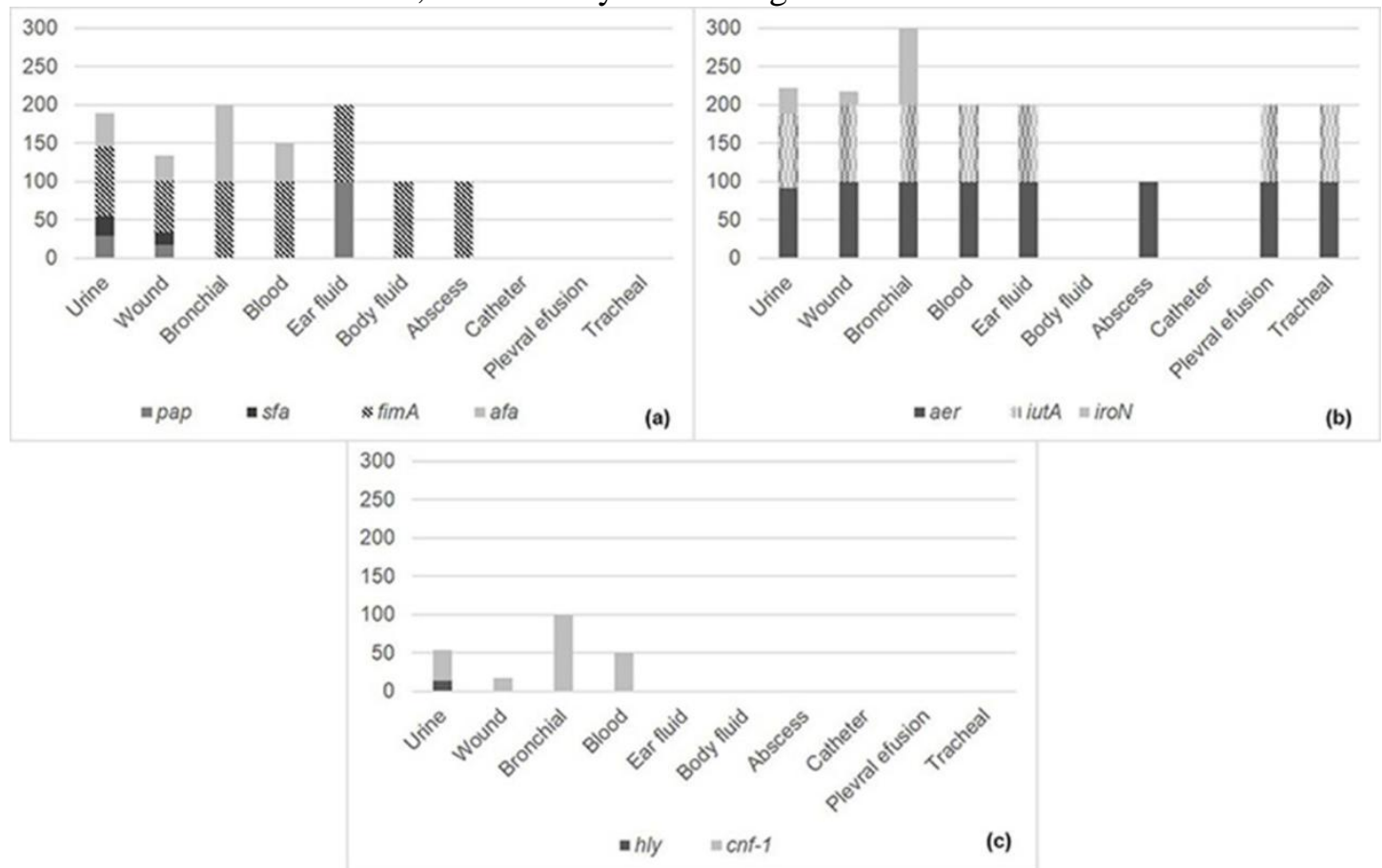

Figure 4. Distribution $(\%)$ of virulence genes (a; fimbriae, b; siderophore, c; others) in different clinical sources (urine; 35, wound; 6, blood; 2, bronchial; 1, ear fluid; 1, body fluid; 1, abscess; 1, catheter; 1, plevral efusion; 1 , tracheal; 1 strain). 
Virulence factor gene profiles of $\boldsymbol{E}$. coli isolates

In this study, when the carbapenem and virulence gene profiles are evaluated and 24 types of virulence profiles are identified (Table 3). In total, $98 \%$ of the strains carry at least one virulence gene.

Table 3. Carbapenem resistance and virulence gene profiles of E.coli strains

\begin{tabular}{|c|c|c|c|}
\hline Strains & Clinical source & Carbapenem resistance & Virulence gene profiles \\
\hline 29 & Catheter & OXA-48 & not determined \\
\hline 44 & Body fluid & susceptible & $\operatorname{fim} A$ \\
\hline 48 & Urine & susceptible & \\
\hline 41 & Urine & OXA-48 & fimA, iutA \\
\hline 1 & Abscess & susceptible & fimA, aer \\
\hline 28 & Plevral efusion & OXA-48 & aer, iutA \\
\hline 32 & Wound & OXA-48 & \\
\hline 35 & Wound & OXA-48 & \\
\hline 36 & Tracheal & OXA-48 & \\
\hline 30 & Urine & susceptible & \\
\hline 49 & Urine & susceptible & \\
\hline 27 & Urine & susceptible & aer, iutA, cnf-1 \\
\hline 7 & Urine & susceptible & fimA, aer, iutA \\
\hline 19 & Urine & susceptible & \\
\hline 40 & Urine & susceptible & \\
\hline 43 & Wound & susceptible & \\
\hline 33 & Urine & OXA-48 & fimA, sfa, aer, iutA \\
\hline 18 & Urine & susceptible & fimA, pap, aer, iutA \\
\hline 45 & Urine & susceptible & \\
\hline 46 & Ear fluid & susceptible & \\
\hline 37 & Blood & OXA-48 & fimA, afa, aer, iutA \\
\hline 5 & Urine & susceptible & \\
\hline 8 & Urine & susceptible & \\
\hline 9 & Urine & susceptible & \\
\hline 24 & Wound & susceptible & \\
\hline 25 & Wound & susceptible & \\
\hline 50 & Urine & susceptible & \\
\hline 31 & Urine & OXA-48 & fimA, aer, iutA, cnf-1 \\
\hline 4 & Urine & susceptible & \\
\hline 6 & Urine & susceptible & \\
\hline 17 & Blood & susceptible & \\
\hline 34 & Urine & susceptible & fimA, sfa, aer, iutA, iroN \\
\hline 38 & Urine & OXA-48 & fimA, pap, aer, iutA, hly \\
\hline 16 & Urine & susceptible & fimA, pap, aer, iutA, iroN \\
\hline 21 & Urine & susceptible & fimA, pap, afa, aer, iutA \\
\hline 26 & Urine & susceptible & \\
\hline
\end{tabular}




\begin{tabular}{llll}
\hline 3 & Urine & susceptible & fimA, afa, aer, iutA, cnf-1 \\
20 & Urine & susceptible & \\
12 & Urine & susceptible & fimA, pap, afa, aer, iutA, iroN \\
15 & Urine & susceptible & \\
23 & Urine & susceptible & fimA, sfa, afa, iutA, iroN, cnf-1 \\
2 & Bronchial & susceptible & fimA, afa, aer, iutA, iroN, cnf-1 \\
13 & Urine & susceptible & \\
22 & Urine & susceptible & fimA, sfa, aer, iutA, iroN, hly, cnf-1 \\
47 & Urine & susceptible & \\
11 & Urine & susceptible & fimA, sfa, afa, aer, iutA, iroN, cnf-1 \\
42 & Wound & susceptible & fimA, pap, sfa, aer, iutA, iroN, cnf-1 \\
39 & Urine & OXA-48 & fimA, pap, sfa, aer, iutA, iroN, , ily, cnf-1 \\
10 & Urine & susceptible & fimA, sfa, afa, aer, iutA, iroN, hly, cnf-1 \\
14 & Urine & susceptible & fimA, pap, sfa, afa, aer, iutA, iroN, cnf-1 \\
\hline
\end{tabular}

When the virulence profiles in Table 3 are examined, carbapenem resistant E.coli isolated from catheter (strain 29) was not included any virulence gene regions. On the other hand, carbapenem resistant E.coli (strain 39) isolated from urine has eight virulence gene regions and the strain is the most virulent isolate among other.

\section{Correlation between virulence genes and carbapenem resistance}

The overall virulence factor productions between carbapenem resistant $(n=11)$ and carbapenem susceptible $(n=39)$ E.coli strains are shown in Table 4. Correlation between the presence of the fimA or afa gene regions and carbapenem resistance was statistically significant $(P<0.05)$. Most of E.coli strains carrying these genes were susceptible to carbapenem.

Table 4. Distribution of carbapenem resistant and susceptible E.coli strains

\begin{tabular}{llll}
\hline $\begin{array}{l}\text { Virulence } \\
\text { factors }\end{array}$ & $\begin{array}{l}\text { Carbapenem } \\
\text { strains }(\mathrm{n}=11)(22 \%)\end{array}$ & $\begin{array}{l}\text { resistant } \\
\text { Carbapenem susceptible strains } \\
(\mathrm{n}=39)(78 \%)\end{array}$ & $P$ value \\
\hline pap & $2(18)$ & $10(26)$ & $>0.05$ \\
sfa & $2(18)$ & $8(21)$ & $>0.05$ \\
fimA & $6(55)$ & $36(92)$ & $<\mathbf{0 5}$ \\
afa & $1(9)$ & $18(46)$ & $<\mathbf{0 . 0 5}$ \\
hly & $2(18)$ & $3(8)$ & $>0.05$ \\
cnf-1 & $2(18)$ & $15(38)$ & $>0.05$ \\
iutA & $10(91)$ & $36(92)$ & $>0.05$ \\
aer & $9(82)$ & $36(92)$ & $>0.05$ \\
iroN & $1(9)$ & $13(33)$ & $>0.05$ \\
\hline
\end{tabular}

\section{DISCUSSION}

Serine carbapenemases (KPC and OXA-48) and metallo-beta-lactamases (VIM, IMP and NDM) are frequently found in the members of the Enterobacteriaceae. ${ }^{20}$ OXA48 type carbapenemases are commonly reported in E.coli ${ }^{21}$ and recently $\mathrm{NDM}^{22}$, $\mathrm{IMP}^{23}$ and $\mathrm{KPC}^{24}$ type carbapenemases have also been determined. In our study, 
only OXA-48 type resistance is found in E.coli isolates. This plasmid-based resistance has been reported in Turkey and around the world and it is more common than other types of resistance. .,25,26 $^{-1}$

Siderophores are the most important virulence factor supporting bacterial infection in tissues and blood, in case of there is iron deficiency. Aerobactin and ferric aerobactin expressed by aer and iutA gene regions are important siderophores in E.coli virulence and commonly found in many isolates. ${ }^{10,11}$ In this study, it is found that the most common regions for these genes were related with siderophores.

aer gene was reported to have the highest ratio among the virulence factor genes. ${ }^{13,27}$ Besides, a study with extrainstestinal E.coli isolates, the highest iutA gene region within virulence gene regions was found and this gene region was not determined in the control isolates. ${ }^{12}$ In our study, another siderophore related gene region is iroN. This gene region is responsible of salmochelin and causes invasion in urothelial cells. ${ }^{11}$ And also, this gene region was reported to have the highest ratio after iutA. ${ }^{12}$ Another virulence gene region found with high incidence in our study was fimA which is related to Type I fimbriae. This gene, commonly found most of the E.coli isolates, is observed both pathogenic and commensal isolates despite being an important virulence factor. ${ }^{6,8}$ Similarly, it was reported in many studies that this gene region was more than other fimbria types. ${ }^{12,27,28}$

Urinary tract infections (cystitis, pyelonephritis etc.) which are considerably common and seen by many different symptoms ${ }^{8,29}$, the virulence factor diversity is mostly found in urine samples in this study. The most important virulence factors for urinary tract infections are fimbriae. It was reported that no important difference in presence frequency of type I fimbria between low and high virulence isolates in the urinary tract. ${ }^{30}$ In our study, fimA was found in most of the urine samples. Similarly, in Johnson et al., this gene region, despite commonly found in most E.coli isolates, is thought to be specific gene region for urinary tract infection. ${ }^{28}$

pap gene region, particularly with pyelonephritis, plays an important role in pathogenesis of uropathogenic E.coli, and this gene region is highly found in the isolates of urinary tract infection ${ }^{29}$ and kidneys. ${ }^{31}$ Thus, this gene region is found almost three-fold lower than the results reported before. On the other hand similar result were reported in our study. ${ }^{13}$ For all the studies, even for the ones with high or low percentage, it is clear that this gene region is mostly related to complicated urinary tract infections.

The decay acceleration factor (DEF) in humans, which is a glycoprotein found in hemopoietic, endothelial, intestinal and urinary cells, is a receptor for afimbrial adhesin expressed with afa gene region. ${ }^{6}$ In our study, this gene was found in urine samples as well as blood and bronchial samples. Sfa gene region related with $\mathrm{S}$ fimbria is found in urinary tract infections as well as infections such as sepsis, meningitis like afa gene region. ${ }^{8}$ These gene regions were reported in none ${ }^{29}$ or low percentage $e^{28}$ of the samples isolated complicated urinary tract infection and there are no specific gene regions for these infections.

Siderophores in urinary tract infections are virulence factors frequently found in most pathogenic types of E.coli after fimbria. Even though, iutA gene region was reported in high incidence in complicated urinary tract infection compared to control group and acute cholangite. ${ }^{29}$ Landgraf et al. reported that relation between iutA gene and uropathogenics was low. ${ }^{32}$ Also, salmochelin (iroN) was found higher than ferric aerobactin (iutA) in several types' urinary tract infections. ${ }^{11,28}$ In our study, presence of aer and iutA gene regions in many types of clinical strains and iroN gene in urine shows that this gene is a siderophore specific to urinary tract infection.

Hemolysin (hly) is produced by various pathogenic types of E.coli causing extraintestinal and intestinal infections, but its effect on virulence is not completely clarified. ${ }^{6,8}$ hly gen region being related with complicated urinary tract infections 
such as pyelonephritis and cystitis is reported by many researchers. ${ }^{8,27,29}$ Similarly, cnf- 1 gene region is produced in one third of the isolates causing pyelonephritis and kidney invasion. ${ }^{8}$ These gene regions are especially important in development of inflammation in urinary tract infections. ${ }^{33}$ Also in our study, cnf- 1 gene region was highly found in urine and hly gene region was only found in urine.

Although no statistically important relation found between carbapenem resistance and virulence factors in this study, the effect of beta-lactam resistance in virulence is known. The relation between the virulence factors and ESBL in E.coli were reported by many researchers. ${ }^{34,35}$ Also, Arisoy et al. reported that increase of virulence genes were related with resistance to some antibiotics or sensitivity to others. ${ }^{13}$ In recent studies, a few mechanisms were focused for the relation and one of the mechanism is the plasmids carrying antibiotic resistance [36] and others are porin $\operatorname{loss}^{37}$, modifications in penicillin binding proteins and efflux pumps mechanism. ${ }^{38}$ Efflux pumps are responsible for discharging of molecules containing virulence factors regulated by quorum sensing which has a positive effect on antibiotics resistance and virulence. ${ }^{39,40}$ E.coli strain 28 which previously reported with porin loss and OXA-48 resistance $^{25}$, was determined to have gene regions related with siderophore (aer, iutA) in this study. Similarly, virulence factors were highly found in carbapenem susceptible isolates, shows that other mechanisms may have an effect on the relation between carbapenem resistance and virulence. Therefore, determining of beta-lactam group resistance, these mechanisms should be taken into consideration.

\section{CONCLUSIONS}

Consequently, results demonstrated that virulence factors, antibiotic resistance, porin loss, multi drug efflux pump and quorum sensing molecules should be considered collective manner in the further studies about bacterial pathogenesis for developing effective treatments.

\section{ACKNOWLEDGEMENTS}

The data of this study have been excerpted from the $\mathrm{PhD}$ thesis of the author. The authors thank Assoc Prof Abbas Yousefi Rad, Assoc Prof Ayşe Esra Karakoç and Sefer Erman Yılmaz, MD for collecting clinical specimens, Onur Candan, $\mathrm{PhD}$, for comments and suggestions and Çağla Kılıç MSc, for her contribution to this study. This work was financed by Hacettepe University Scientific Research Project grant 014D01601002 and The Scientific and Technological Research Council of Turkey (TUBITAK) with PhD Scholarship (2211/C).

\section{REFERENCES}

1. Blondeau JM. Current issues in the management of urinary tract infections: Extendedrelease ciprofloxacin as a novel treatment option. Drugs 2004;6: 611-28.

2. Falagas ME, Karageorgopoulos DE. Extended-spectrum beta-lactamase-producing organisms. Journal of Hospital Infection 2009;73:345-54.

3. McLaughlin M, Advincula MR, Malczynski M, Qi C, Bolon M, Scheetz MC. Correlations of Antibiotic Use and Carbapenem Resistance in Enterobacteriaceae, Antimicrobial Agents and Chemotherapy 2013;57:5131-3.

4. Naas T, Nordmann P. Analysis of a carbapenem hydrolyzing class A b-lactamase from Enterobacter cloacae and of its LysR-type regulatory protein. Proceedings of the National Academy of Sciences U.S.A. 1994,91:7693-7.

5. Nordmann P, Naas T, Poirel L. Global Spread of Carbapenemase-producing Enterobacteriaceae. Emerging Infectious Diseases 2011;17:1791-8. 
6. Mainil J. Escherichia coli virulence factors. Veterinary Immunology and Immunopathology 2013;152:2-12.

7. Wang MC, Tseng CC, Chen CY, Wu JJ, Huang JJ. The role of bacterial virulence and host factors in patients with Escherichia coli bacteremia who have acute cholangitis or upper urinary tract infection. Clinical Infectious Diseases 2002;15:1161-6.

8. Bien J, Sokolova O, Bozko P. Role of Uropathogenic Escherichia coli Virulence Factors in Development of Urinary Tract Infection and Kidney Damage. International Journal of Nephrology 2012;681473.

9. Dobrindt U, Blum-Oehler G, Hartsch T. S-fimbria-encoding determinant sfaI is located on pathogenicity island III536 of uropathogenic Escherichia coli strain 53. Infection and Immunity 2001;69:4248-42.

10. Demir M, Kaleli I. Production by Escherichia coli isolates of siderophore and other virulence factors and their pathogenic role in a cutaneous infection model. Clinical Microbiology and Infection 2004;10:1011-4.

11. Henderson JP, Crowley JR, Pinkner JS, Walker JN, Tsukayama P, Stamm WE et al. Quantitative Metabolomics Reveals an Epigenetic Blueprint for Iron Acquisition in Uropathogenic Escherichia coli. PLoS Pathogens. 2009;5:e1000305.

12. Koga VL, Tomazetto G, Cyoia PS, Neves MS, Vidotto MC, Nakazato G, et al. Molecular Screening of Virulence Genes in Extraintestinal Pathogenic Escherichia coli Isolated from Human Blood Culture in Brazil. BioMed Research International, 2014; $15: 2014: 465054$.

13. Arısoy M, Yousefi Rad A, Akın A, Akar N. Relationship between susceptibility to antimicrobials and virulence factors in pediatric Escherichia coli isolates. International Journal of Antimicrobial Agents 2008;31,4-8.

14. Guiral E, Bosch J, Vila J, Soto SM. Prevalence of Escherichia coli among samples collected from the genital tract in pregnant and nonpregnan two men: relationship with virulence. FEMS, Microbiology Letters 2011;314:170-3.

15. Welinder-Olsson C, Eriksson E, Kaijser B. Virulence genes in verocytotoxigenic Escherichia coli strains isolated from humans and cattle. APMIS 2005;113:577-85.

16. Saito R, Koyano S, Nagai R, Okamura N, Moriya K, Koike K. Evaluation of a chromogenic agar medium for the detection of extended-spectrum beta-lactamaseproducing Enterobacteriaceae. Letters in Applied Microbiology 2010;51:704-6.

17. Panagea T, Galani I, Souli M, Adamou P, Antoniadou A, Giamarellou H. Evaluation of CHROMagarTM KPC for the detection of carbapenemase-producing Enterobacteriaceae in rectal surveillance cultures. International Journal of Antimicrobial Agents 2011;37:124-8.

18. Poirel L, Walsh TR, Cuvillier V, Nordmann P. Multiplex PCR for detection of acquired carbapenemase genes. Diagnostic Microbiology and Infectious Disease 2011;70:119-123.

19. Ruiz J, Simon K, Horcajada JP, Velasco M, Barranco M, Roig G et al. Differences in Virulence Factors among Clinical Isolates of Escherichia coli Causing Cystitis and Pyelonephritis in Women and Prostatitis in Men. J. Clin. Microbiol. 2002;40:4445-9.

20. Walsh TR. Emerging carbapenemases: A global perspective. Int. J. of Antimicrob. Agents 2010;36:8-14.

21. Poirel L, Yilmaz M, Istanbullu A, Arslan F, Mert A. Spread of NDM-1-producing Enterobacteriaceae in a neonatal intensive care unit, Istanbul, Turkey. Antimicrobial Agents and Chemotherapy 2014;58:2929-33.

22. Mushtaq S, Irfan S, Sarma JB, Doumith M, Pike R, Pitout J et al. Phylogenetic diversity of Escherichia coli strains producing NDM-type carbapenemases. J. Antimicrob. Chemother. 2011;66:2002-5.

23. Aktas Z, Satana D, Kayacan C, Ozbek B, Gurler N, Somer A et al. Carbapenem resistance in Turkey: Repeat report on OXA-48 in Klebsiella pneumoniae and first report on IMP-1 beta-lactamase in Escherichia coli. African Journal of Microbiology Research 2012;6:3874-8.

24. Morris D, Boyle F, Ludden C, Condon I, Hale J, O'Connell N et al. Production of KPC-2 Carbapenemase by an Escherichia coli Clinical Isolate Belonging to the International ST131 Clone. Antimicrob. Agents Chemother. 2011;55:4935-6.

25. Gülmez D, Woodford N, Palepou Marie-France I, Mushtaq S, Metan G, Yakupogullari Y et al. Carbapenem-resistant Escherichia coli and Klebsiella pneumoniae isolates from 
Turkey with OXA-48-like carbapenemases and outer membrane protein loss. International Journal of Antimicrobial Agents 2008;31:523-6.

26. Carrer A, Poirel L, Yılmaz M, Arikan Akan Ö, Feriha C, Cuzon G et al. Spread of OXA48-Encoding Plasmid in Turkey and Beyond. Antimicrobial Agents and Chemotherapy 2010;54:1369-73.

27. Tarchouna M, Ferjani A, Ben-Selma W, Boukadida J. Distribution of uropathogenic virulence genes in Escherichia coli isolated from patients with urinary tract infection. International Journal of Infectious Diseases 2013;17:e450-3.

28. Johnson JR, Kuskowski MA, Gajewski A, Soto S, Horcajada JP, Jimenez de Anta MT et al. Extended Virulence Genotypes and Phylogenetic Background of Escherichia coli Isolates from Patients with Cystitis, Pyelonephritis, or Prostatitis. The Journal of Infectious Diseases 2005;191:46-50.

29. Wang MC, Tseng CC, Chen CY, Wu JJ, Huang JJ. The role of bacterial virulence and host factors in patients with Escherichia coli bacteremia who have acute cholangitis or upper urinary tract infection. Clinical Infectious Diseases 2002;15:1161-6.

30. Plos K, Lomberg H, Hull S, Johansson I, Svanborg C. Escherichia coli in patients with renal scarring: genotype and phenotype of Gal alpha 1-4Gal beta-, Forssman- and mannose-specific adhesins. Pediatric Infectious Disease Journal 1991;10:15-9.

31. Roberts J, Marklund B, Ilver D, Haslam D, Kaak M, Baskin B et al. The Gal(alpha 14)Gal-specific tip adhesin of Escherichia coli P-fimbriae is needed for pyelonephritis to occur in the normal urinary tract, Proceedings of the National Academy of Sciences U.S.A. 1994;91:11889-93.

32. Landgraf TN, Berlese A, Fernandes FF, Milanezi ML, Martinez R, Panunto-Castelo A. The ferric aerobactin receptor iutA, a protein isolated on agarose column, is not essential for uropathogenic Escherichia coli infection. Revista Latino-Americana de Enfermagem 2012;20:340-5.

33. Garcia TA, Ventura CL, Smith MA, Merrell DS, O'Brien AD. Cytotoxic Necrotizing Factor 1 and Hemolysin from Uropathogenic Escherichia coli Elicit Different Host Responses in the Murine Bladder. Infection and Immunity 2013;81:99-109.

34. Pitout JDD, Laupland KB, Church DL, Menard ML, Johnson JR. Virulence Factors of Escherichia coli Isolates That Produce CTX-M-Type Extended-Spectrum $\beta$-Lactamases. Antimicrob. Agents Chemother. 2005;49:4667-70.

35. Sharma S, Bhat GK, Shenoy S. Virulence factors and drug resistance in Escherichia coli isolated from extraintestinal infections. Indian Journal of Medical Microbiology 2007;25:369-73.

36. Fekete PZ, Brzuszkiewicz E, Blum-Oehler G, Olasz F, Szabó M, Gottschalk G et al. DNA sequence analysis of the composite plasmid pTC conferring virulence and antimicrobial resistance for porcine enterotoxigenic Escherichia coli. International Journal of Medical Microbiology 2012;302:4-9.

37. Rolhion N, Carvalho FA, Darfeuille-Michaud A. OmpC and the sigma(E) regulatory pathway are involved in adhesion and invasion of the Crohn's disease-associated Escherichia coli strain LF82. Molecular Microbiology 2007;63:1684-700.

38. Beceiro A, Tomás M, Bou G. Antimicrobial Resistance and Virulence: a Successful or Deleterious Association in the Bacterial World? Clinical Microbiology Reviews 2013;26:185-230.

39. Yang YX, Xu ZH, Zhang YQ, Tian J, Weng LX, Wang LH. A new quorum-sensing inhibitor attenuates virulence and decreases antibiotic resistance in Pseudomonas aeruginosa. Journal of Microbiology 2012;50:987-93.

40. Wang H, Tu F, Gui Z, Lu X, Chu W. Antibiotic resistance profiles and quorum sensingdependent virulence factors in clinical isolates of Pseudomonas aeruginosa. Indian Journal of Microbiology 2013;53:163-7. 